\title{
LAWYERS, SCHOLARS, AND THE "MIDDLE GROUND"
}

\author{
Robert W. Gordon*
}

One of the many virtues of Judge Harry Edwards' very interesting polemic $^{1}$ is that it issues an open invitation to say what one likes about present legal scholarship, without having to document it too carefully; and it provokes one to more than perfunctory reflection about what to say.

Judge Edwards has three complaints. (1) $\mathrm{He}$ and his clerks have had trouble lately finding law review articles that bear directly on the legal questions he needs to answer. (2) Instead, he finds far too much "impractical" scholarship ${ }^{2}$ — usually theoretical, interdisciplinary ("law and"), or critical work - which is of little or no help to practitioners. Either it does not address any legal "problem" they "must resolve,"3 or it does address legal problems but uses resources other than "authoritative legal materials" to resolve them. ${ }^{4}$ (3) Judge Edwards' third complaint is about legal practice, especially as carried on in law firms. In recent years, firm lawyers have been driven to pursue profits to the point of neglecting other values, especially those of ethical and public-spirited practice.

Not satisfied to rely entirely on his own impressions, Judge Edwards has done an informal survey of thirty of his former law clerks, who mostly confirm his findings. Then the judge ingeniously rolls his three complaints into one: a general thesis of declension. Both law schools and law firms, he says, have fallen away from their "proper place": the schools by "emphasizing abstract theory at the expense of practical scholarship and pedagogy," the firms by "pursuing profit above all else." While the schools, filled with scholars increasingly

* Professor of Law, Stanford University. - Ed. I would like to thank Ariela Gross for research into the contents of law reviews and for many discussions that clarified my thinking about this subject; and Bob Weisberg and Tom Grey for useful comments on an earlier draft. This work was supported by a bequest from the Claire and Michael Brown Estate.

1. Harry T. Edwards, The Growing Disjunction Between Legal Education and the Legal Profession, 91 MICH. L. REV. 34 (1992).

2. Id. at 46.

3. Id.

4. Id. at 47 . Articles written from the perspective of critical legal studies exemplify the first vice, law and economics, the second.

5. Id. at 34. 
"disdainful of the practice of law"6 are "moving toward pure theory, the firms are moving toward pure commerce, and the middle ground - ethical practice - has been deserted by both. This disjunction calls into question our status as an honorable profession."7

A suggestive parallel, is it not? The Judge seems to be arguing that both teachers and firm lawyers have been seduced from their real vocation by the fatal attraction of neighboring cultures: the practitioners by the commercial culture of their business clients, the academics by the disciplinary paradigms and prestige of theory in the rest of the university. The "deserted middle ground" is the ground of professional practice - practical, yet also public-minded. Perhaps without straining his thesis too far we could ascribe to Judge Edwards a "republican" view of the legal profession, in which legal scholars, practitioners, judges, legislators, and administrators - despite their separate interests and distinct roles in a division of labor - are all participants in a common enterprise. They are, or at any rate ought to be, engaged in trying to construct the legal system as a medium in which the pursuit of private advantage - their own and that of their clients and constituencies - can be aligned with some plausible conception of the public interest.

If Judge Edwards has something like this in mind, I have a lot of sympathy with it. ${ }^{8}$ And I have to admit right away that his critique of current legal scholarship, though I will be arguing shortly that it is an indiscriminate and overgeneralized critique, has a gritty core of unpleasant truth. The legal-academic machine is undoubtedly cranking out a good deal of useless blather: articles that seem to have hardly anything to do with addressing or understanding any legal problem, articles clotted with hermetic jargon or puffed up with self-indulgent

6. Id. at 35 .

7. Id. at 34 .

8. I am one of a group of scholars who have been pushing for a revival of the view that even private lawyers working for private clients ought to behave as members of a public profession pursuing public values and purposes. We have defended that view against the powerful rival position that the only proper public concern of lawyers is to avoid flat disobedience of clear positive legal and ethical rules while zealously pursuing the self-interest of their clients as those clients perceive it. See David LuBAN, LAwYers AND Justice (1988); Richard L. Abel, Taking Professionalism Seriously, 1989 ANN. SuRv. AM. L. 41; Robert W. Gordon, Corporate Law Practice as a Public Calling, 49 MD. L. REv. 255 (1990) [hereinafter Gordon, Corporate Law Practice]; Robert W. Gordon, The Independence of Lawyers, 68 B.U. L. REV. 1 (1983); Deborah L. Rhode, Ethical Perspectives on Legal Practice, 37 STaN. L. Rev. 589 (1985); William H. Simon, Babbitt v. Brandeis: The Decline of the Professional Ideal, 37 STAN. L. REv. 565 (1985); William H. Simon, Ethical Discretion in Lawyering, 101 HARv. L. REv. 1083 (1988); William H. Simon, Visions of Practice in Legal Thought, 36 STAN. L. REv. 469 (1984) [hereinafter Simon, Visions]; David B. Wilkins, Legal Realism for Lawyers, 104 HARV. L. REv. 468 (1990) [hereinafter Wilkins, Legal Realism for Lawyers]; David B. Wilkins, Who Should Regulate Lawyers?, 105 HARv. L. REV. 799 (1992). 
posturing, articles clumsily practicing intellectual modes that people in other fields execute with much more grace and precision, articles borrowing intellectual fashions that would be better off never having been invented. But Judge Edwards' vision of what we should be doing, of what the "middle ground" of practical-yet-public-minded professionalism ought to look like, is incredibly, even distressingly, narrow - indeed very much narrower than any of the major views of professionalism and the proper functions of legal scholarship that commentators have entertained since the creation of the modern bar and modern law school in the late nineteenth century. ${ }^{9}$ In what follows I would like to explain what I think Judge Edwards' vision of the professional enterprise is, and why I think it is unacceptably limited. Moreover, I want to specify how a broader vision would reveal that a good deal of the scholarship that Judge Edwards believes is irrelevant to the professional enterprise is practically useful, or would be if anyone wanted to use it. I will finish by offering my own speculations on the reasons scholars and practitioners are discontented with one another and by gesturing vaguely in the direction of possible remedies.

\section{EDWARDS' MOdAl Legal ACTIVITY: JUDICIAL-DOCTRINAL DISCOURSE}

Judge Edwards thinks that what lawyers do, what they should be taught how to do, and what most legal scholarship should address is law. Further, his idea of the core legal activity is his own principal activity, the production of judicial doctrine, that is, case law. The most important equipment one needs to perform this activity is knowledge of existing conventional rules and craft skill in operating the conventional method of their application - for example, arguing from precedent and reading statutes. ${ }^{10}$ This set of skills is not only necessary, but also sufficient, for handling ninety percent of cases, the "easy" cases that one can readily resolve by finding, and then applying, the settled authoritative law.

Evidently, Judge Edwards is taking up a strong position on greatly disputed issues of jurisprudence. His jurisprudence is central to his thesis because it defines the scope of what he considers "relevant" and

9. To be fair I must mention that Judge Edwards repeatedly disclaims any desire to exclude any kind of scholarship, however impractical, from the legal academy. He says often that there is a "place" for theoretical, interdisciplinary, and critical scholarship, though he wishes it were smaller. In making these concessions he proves himself more generous and cosmopolitan than many inhabitants of the legal academy.

10. Later in his article, Judge Edwards significantly adds another skill — that of "ethical" or public-minded interpretation of legal materials. Edwards, supra note 1, at 59. I will come back to this point. See infra text accompanying note 50 . 
"practical" contributions from scholars. His position depends on a conception of the judge as primarily a law-declarer and only marginally and incrementally a policymaker. The great mass of the law at any time is already settled. There is a fringe of "hard cases" - perhaps, though he is not clear about this, a receding fringe of historical anachronisms ripe for judicial repeal, an advancing fringe of modern tendencies ripe for judicial innovation, and some other fringe areas where current law is conflicting or confused. To work in the fringe areas, it is useful for lawyers to have some familiarity with "theory" and "policy" and the ability to argue from them. But this set of skills is distinctly secondary because it is "practical" only in a very limited set of contexts, the ten percent involving argument over "hard cases." For Judge Edwards, it follows from this account of the core legal activity that the main business of scholars should be to help judges, and lawyers arguing before them, to "find" the existing law - all presented in the conventional form of judicial-doctrinal discourse. "Practical" scholarship thus ideally takes the form of the article addressed to some specific knotty doctrinal problem that is already, or soon likely to be, before the courts; or, even better, of the treatise devoted to encyclopedic exposition of all the doctrine in some legal field.

Judge Edwards' view of legal reasoning is undoubtedly widespread in our legal culture. It still seems to be the official view, in the sense that judges and lawyers arguing before judges feel constrained to talk as if it were true. It is reflected in the distinction one often hears made between "legal" and "policy" arguments. But it is hardly the only view around. Most modern lawyers even faintly influenced by legal realism - which category probably would include most law teachers nowadays and not a few judges ${ }^{11}$ - would call this a "prerealist" or "formalist" position and reject it. They would argue that, although doctrine supplies the language of legal - or rather, judicial - decisionmaking, it is not the major factor in deciding cases and that purely doctrinal scholarship is therefore of quite limited utility. Outside the restricted area of practice before the courts, which is only a small part of what actors in our legal system do, doctrine is even less useful.

\section{Some Modal Types of Legal Scholarship, Along With ARguMENTS FOR THEIR PRACTICAL UTILITY}

I will return in a moment to what might be meant by "postrealist" law practice and the sorts of scholarship designed to support it. For

11. For an example of a judge thoroughly drenched in realism, save for an Achilles' heel of residual formalist faith in microeconomics and sociobiology, see RICHARD A. POSNER, THE Problems of JURISPRUdence (1990). 
now I would like to point out that even if one were to accept Judge Edwards' apparently prerealist view of judging, one might still think his notions of "practical" scholarship are unduly restrictive. He would like us to spend most of our time on doctrinal exposition for judges.

\section{Type \# 1: Traditional Legal Science, or, Retheorizing the Case Law}

Even the heroic treatise writers of the classical age of formalism (1880-1920) that Judge Edwards apparently wants to restore had a more ambitious view of their function than to present the existing doctrines. True, they did try to collect and keep up with all the case law in their fields. But their real aspiration was to do "legal science" not just to collect and arrange the cases, but to show how they might be rationalized in terms of general concepts or principles. The early writers on contracts and torts, for example, were not content just to lay out the common law as they found it, which was a motley assortment of miscellaneous "actions on the case" - "a chaos with a full index," as Holmes called it. ${ }^{12}$ Instead they stretched and pounded the doctrine into a greatly simplified - and hence ultimately much more useful - order, creating in the process many of our modern categories such as the distinctions among contract, quasi-contract and tort, and among intentional, negligent, and strict bases of tort liability.

This enterprise of reconceptualizing the principled bases of doctrine was surely highly theoretical, in Judge Edwards' terms. Indeed its motto, to quote Holmes again, was that "[w]e have too little theory in the law rather than too much."13 It relied heavily on historical research too, not for reasons of antiquarian curiosity, but because the scholars believed that only the study of the development of legal doctrines could reveal their organizing conceptions. It was also critical and reformist in spirit. The everyday official doctrine as expounded in the courts, said the scholars, was often useless for sorting out the cases and understanding their "true basis" in principle. Critical retheorizing in the articles and treatises was hardly limited to the "hard cases" in the fringe areas. Its subject was the mass of routine cases: the aim

12. Holmes actually borrowed this phrase from the English jurisprude T.E. Holland. See Book Notice, 5 AM. L. REv. 114, 114 (1870) (reviewing ThOMAS E. HollaND, EsSAYS UPON THE FORM OF LAW (London, Butterworths 1870)) (quoting THOMAS F. Holland, The Classifcation of Statutes, in ESSAYS, supra, at 171). For Holmes' authorship of this review, see SHELDON M. Novick, Honorable Justice: The Life of Oliver WeNdell Holmes 402 (1989) (listing Holmes' publications in the American Law Review).

13. Oliver W. Holmes, The Path of the Law, in Collected Legal Papers 167, 198 (1920). 
was to rethink entire areas of doctrine. ${ }^{14}$ The scholars' articles and treatises were designed to reshape the minds and reform the practices of practitioners and judges, not just to supply handy research aids. In short, the bargain that the early academics aimed to strike with the bar was basically this: "We'll collect and give you cites to all the cases, if you'll adopt our theoretical schemes and reform proposals." If the scholars were lucky, as they frequently were, the bench and bar would pick up on the new formulations, which would find their way into restatements and the opinions of distinguished judges, and eventually become the common sense of the field.

The failure of judges and practitioners to pick up their reform ideas did not discourage the scholars of the classical age, who promptly turned to legislation. An important aspect of the "Vocation of the Law Professor," as Dean James Barr Ames put it, was to master the "science" of law in order to become an "expert counselor in legislation"; 15 many scholars were active in the drafting of uniform state laws and other reform statutes, as of course academics still are today.

Currently a good deal of legal scholarship and teaching simply carries on this "classical" project of trying to find a theory that will effectively organize and rationalize the cases better than the official doctrine does. Those of us who teach contracts, for instance, know that the standard doctrinal test for "duress" - whether consent was induced by a threat that overcame the party's "free will" — is totally unworkable. It cannot be operationally applied and does not tell you anything at all about which kinds of pressure will make the deal voidable and which will not. Of course we still teach the doctrinal formula, the "free will" test, because that is the language many courts - despite the efforts of generations of law reformers - expect to hear. But we would be complete derelicts as trainers of future lawyers if we allowed our students to think the "free will" test made sense and if we did not help them to find a formulation outside the recognized doctrine that would serve them better. A lot of theory is needed to work effectively with the easy cases of the system, never mind the hard ones.

14. One of the first treatises of the classical age, for example, JAMES B. THAYER, A PRELIMINARY TReatise on Evidence at the Common LAW (Boston, Little, Brown \& Co. 1898), undertook what was for the time a radical reordering of the field. Thayer's work was built around a powerful organizing theory: that most standard "evidence" rules were not about evidence at all, but rules of substantive law, which scholars should precipitate out of the field entirely and reassign to their proper substantive law categories. Once that was done, the remaining rules could be more easily regrouped and retheorized.

15. See JAmes B. Ames, The Vocation of the Law Professor, in Lectures on Legal HisTORY AND MISCELLANEOUS LEGAL ESSAYS 354, 354, 367-68 (1913). 


\section{Type \#2: Realist Legal Science, or Finding the Policy or Value Subtext}

Judge Edwards thinks scholars should write about doctrine because that is what decides the easy cases. The position of lawyers influenced by realism is, of course, that the "real" factors on which courts rely when they frame rules and principles, or choose among broad or narrow readings of precedents or statutes, are likely to lie outside the doctrine - in more or less "[in]articulate major premise[s]"16 of ethics, economics, or politics, or else in situation-specific responses to peculiarities of factual context. Such lawyers, obviously, will continue to prize the ability to argue and rationalize results in the official doctrinal discourse. But they will prize even more the ability to dig beneath the surface of doctrinal rationales to the substratum of "real" decisional factors.

The postrealist scholar, like the classical one, may well start by surveying an area of doctrine, such as the cases on whether modifications in midcontract are enforceable. She finds that conventional doctrine asks whether both parties have supplied a fresh "consideration" for the modification, because if one or the other has promised only to perform a preexisting duty there is no consideration and the modification is unenforceable. She also finds that courts can and often do easily avoid the preexisting duty rule by slipping through any one of a number of doctrinal escape hatches. ${ }^{17}$ She concludes that some policy or value other than the nominal (consideration) doctrine must "really" lie behind the decisions: perhaps the courts want to enforce contract adjustments agreed to in good faith but to police against extortionate hold-up games by parties who have locked contract partners into reliance by part performance. She is likely then to search the case law and, if she is enterprising enough, even look outside the case law to typical commercial situations - for clues about what is conventionally thought to be good or bad faith in various contexts. She may well finish up by recommending that the modification doctrine be altered so that the covert "real" basis of decision becomes the overt one. If judges want to take up her invitation, fine; if they do not, because they

16. The reference is of course to Lochner v. New York, 198 U.S. 45, 76 (1905) (Holmes, J., dissenting) ("General propositions do not decide concrete cases. The decision will depend on a judgment or intuition more subtle than any articulate major premise."), overruled by Dag-Brite Lighting, Inc. v. Missouri, 342 U.S. 421 (1952), and overruled by Ferguson v. Skrupa, 372 U.S. 726 (1963).

17. These are too boring to specify in the text. Briefly, the court can find that the parties terminated the old agreement and made a new one; that "unexpected difficulties" in performance constitute consideration for a new promise to pay more money for the same work; that the parties had and settled a disputed claim; that the change was a waiver rather than a modification and so does not need consideration. 
are too formalist, too timid, or too inclined to think that explicit policy rationales are outside their province, she will address her argument to law reform commissions or legislatures instead. ${ }^{18}$

Surely almost all American lawyers would immediately recognize this humdrum example for what it is, an exercise that they went through a thousand times in their first year of law school. Indeed I would suppose that this type of postrealist analysis - "Search for the Latent Policy or Value and Make it Explicit" - has (in tandem with the older classical mode of finding latent principles) been the overwhelmingly dominant mode of both scholarship and teaching since the 1940s. It is incredibly ironic that this method should now be condemned as "impractical," because the realist scholars who refined it all believed that it would be far more useful to the practicing profession than pure doctrinal analysis, both for prediction and reform. Advocates skilled at dredging up the latent factors could better guess how courts were likely to decide. Judges and legislatures taught to recognize the functional purposes served by the rules they framed could then revise the rules to make them serve those purposes more effectively. Most lawyers in this realist tradition have urged that the hidden policy and ethical bases of doctrine be more explicitly articulated, both by courts and advocates in argument, so that lawyers could better fit the rules to their appropriate applications. "Covert tools," as Karl Llewellyn liked to say, "are never reliable tools."19 The best of the recent treatises - the sorts of treatises of which Judge Edwards thinks we should have more ${ }^{20}$ - such as Areeda's Antitrust Law ${ }^{21}$ and Clark's Corporate Law, ${ }^{22}$ make extensive use of extrinsic theory (economic theory, in these two cases) to order the discussion of cases and to rationalize their results.

Once again, like old fashioned, classical Type \#1 analysis, this method is not just for the hard case, but for every case; not just for doctrine in the fringe areas of fading rules, emerging rules, and rulesin-conflict, but also, indeed especially, for the standard rules of everyday decisionmaking. In its initial conception in the 1920s and 1930s,

18. Such bodies have, of course, taken up that argument. U.C.C. $\S 2-209$ (1) (1990) abolished the "preexisting duty rule" for contract modifications in sale-of-goods cases. RESTATEMENT (SECOND) OF CONTRACTS $§ 89$ (a) (1981) recommends that courts do the same in the general common law.

19. Karl N. Llewellyn, Book Review, 52 HaRv. L. Rev. 700, 703 (1939) (reviewing O. Prausnitz, The Standardization of Commercial Contracts in ENGlish and ContiNENTAL LAW (1937)).

20. Edwards, supra note 1, at 43-44.

21. Phillip Areeda et al., Antitrust Law: An Analysis of Antitrust Principles AND THEIR APPLiCATIONS (1978 \& Supp. 1992).

22. Robert C. Clark, Corporate law (1986). 
it was not designed as a method exclusively or even primarily for an audience of judges or lawyers practicing before judges. The realist scholars, allied as most of them were to the Progressive movements and ultimately the New Deal, wrote with some judges and practitioners in mind, notably Progressives like themselves: judges like Louis Brandeis, Julian Mack, or Learned Hand; and reform-minded practitioners like Henry Stimson, Grenville Clark, Louis Marshall, Donald Richberg, or Jerome Frank. But the main targets for policy scholarship were naturally the people who the scholars reasonably assumed were taking over the job as the primary lawmakers in modern society - legislators and administrators and the interest and advocacy groups that thought up policy initiatives and helped draft the new statutes and administrative rules. The return of even realist-influenced scholarship in the 1950s to a primary preoccupation with case law - even though this was increasingly the body of case law interpreting the New Deal statutes as well as common law - has been widely, and I think correctly, interpreted as something of a retreat back towards formalism, a withdrawal from practical engagement with the real worlds of politics and social conflict. ${ }^{23}$ To anyone schooled in the realist tradition, a lawyer who sticks exclusively to doctrine-talk is a lawyer who is trying to avoid facing some important aspect of social reality.

One of the principal "law and" schools whose excessive influence Judge Edwards expressly deplores - law and economics - is really nothing more than an extended version of this familiar postrealist method of policy analysis. I would guess that one of the reasons law and economics has so rapidly and easily penetrated legal writing and teaching is that it provides a somewhat more elegant and elaborate method for doing what law teachers were doing already - digging out the latent functions of legal rules and asking whether the rules in force effectively serve them. Judge Edwards complains with some justice that law-and-economics scholars have a single-minded fixation on the norm of "efficiency." Their product will not be useful to a judge or administrator who cannot choose an "efficient outcome" that violates existing law. ${ }^{24}$ But his complaint is surely overstated: "efficiency" in some sense - if only that of reducing "transaction costs" or "deadweight losses" - is usually at least one of the norms or functions that almost any legal rule might be thought to serve, even if it must be balanced or traded off against some other norms. ${ }^{25}$ If the notion of

23. See, e.g., LaUra Kalman, Legal Realism AT YALE 1927-1960, at 188-231 (1986).

24. Edwards, supra note 1, at 47-48.

25. Judge Edwards acknowledges this point. Id. at 49 (stating that efficiency is "an important goal of many legal regimes"). 
"efficiency" were coherent, if "efficient outcomes" were determinate, and if the methods of law and economics could really identify those outcomes - three admittedly rather large and improbable ifs surely knowing what such outcomes were would be very useful information for judges and administrators, even if applicable law told them to consider other values as well.

I must admit my jaw dropped when I came to the part of Judge Edwards' article that seems to argue that even law and economics is not "practical."26 Has the whole recent past been just a bad dream? My impression had been that in the 1980s the methods of law-andeconomics scholars, especially those of the Chicago School, had marched upon and occupied huge areas of legal decisionmaking, especially in the federal executive, and had infiltrated many areas of judicial doctrine as well. President Reagan's executive orders required all the agencies to do "cost-benefit" analyses; the Antitrust Division of the Justice Department incorporated Chicago School antitrust theory in its guidelines; environmental agencies shifted away from commandand-control regulation to economic-incentive-based standards; deregulation statutes shifted traditional regulated industries like trucking and airlines out of regulation entirely into market regimes; the Bureau of Economics at the Federal Trade Commission seized power from the Bureau of Consumer Protection; tort reforms premised on economic analysis were widely proposed, as were "cafeteria" plans of educational and health providers competing with one another other for consumer votes, and still other plans to privatize virtually every remaining public function. Leading law-and-economics scholars were elevated to the federal bench and administrative agencies, which they found very congenial platforms for the application of their theories. This particular "law and" enterprise has become, in Bruce Ackerman's terms, a "new language of power."27

One could certainly wish, as I fervently do, that it were not so pervasive; that those who used it had a keener sense of its flaws and limits than most of them seem to have; that they were more aware of how manipulable economic analysis is, and how many undefended empirical and value assumptions it makes, how annoyingly it drives out other normative concerns, how utterly pernicious its use can be if not informed by any larger social vision. But it is out there, no question about it; no lawyer nowadays who deals with the regulatory state at any level can afford to be ignorant of it. If we in the law schools do

26. See id. at $47-48$.

27. Bruce A. Ackerman, Reconstructing American Law 3 (1984). 
not equip our students both to apply elementary economic analysis to legal problems and to be critical consumers aware of its limits, we will do a lousy job preparing them for practice. Even if many judges and lawyers still hold positions in which they can afford to pay no attention to this discourse, if we follow their example we will not be able to contribute anything to those milieux - health care, education, foreign trade, torts, tax, health and safety, welfare, housing, labor, and environmental policy - where all the policy wonks are at least superficially fluent in economic reasoning.

The appropriate check to the imperial spread of economic analysis is not to ignore it or wish it were not there but to counter it with critique and to educate ourselves and our students in alternative, nonChicago versions. Above all one should develop the capacity, which I think is at present shockingly underdeveloped in the legal profession, to engage in noneconomic, normative argument - arguments based on appeals to morality, history, fairness, equity, community, selfdevelopment, and democracy - in short the kinds of discourse about public values that lawyers were used to engaging in from the beginning of the Republic, before legal discourse became dehydrated and technocratic. Why should we yield the monopoly on discussion of public values to the economists?

\section{Type \#3: Realist Empirical Science, or, Exploring the Contexts and Effects of Legal Decisionmaking}

Another of the legal realists' projects was the study of what they called the "social determinants and effects" of legal regimes and professional practices. What social-environmental conditions are likely to generate different kinds of legal rules and practices? ${ }^{28}$ What social consequences are likely to follow from the adoption of one regime or another? What are the actual social effects of the rules in force: how do the officials or parties who are expected to enforce them translate them into action, how do those rules affect the lives of the people subject to them?

I wish I could say that Type \#3 scholarship was as widespread in the legal academy as Types \#1 and \#2 are. But of course it is not: it remains to this day the most neglected and ridiculously undervalued as well as the most potentially fruitful branch of legal studies. Judge Edwards does not even mention it. Yet there has been significant progress in this area in recent years. The Law \& Society Association,

28. See generally KaLMaN, supra note 23; John H. Schlegel, American Legal Realism and Empirical Social Science: From the Yale Experience, 28 BuFF. L. REv. 459 (1979). 
which carries on the empirical social research project of Realism, is flourishing. Social-legal history, perhaps especially the history of the law of labor relations, has entered a golden age. ${ }^{29}$ Several fields of law, which until recently scholars rarely studied in social context, have begun to develop rich empirical literatures: in labor law, studies of the enforcement of "unfair labor practice" standards, ${ }^{30}$ of changing workplace relations, and shop-floor practices; 31 in administrative law, studies of how agencies actually make decisions; ${ }^{32}$ in bankruptcy law, studies of what happens to companies that go through chapter $11 ; 33$ in employment discrimination, studies of the effectiveness of general job ability testing ${ }^{34}$ and of the social and legal causes of gender segregation; ${ }^{35}$ in procedure, studies of litigation rates ${ }^{36}$ and of settlement regimes; ${ }^{37}$ in criminal law, studies of the kinds of crimes and criminals that are likely to bring on the death penalty ${ }^{38}$ and of the sentencing of white-collar offenders ${ }^{39}$ - to mention just a handful.

This work, needless to say, is not doctrinal. It does not directly supply any lawyer with "authoritative materials" for argument before a court. But at the same time it is intensely practical. A lawyer advising a business contemplating reorganization would surely do well to consult empirical work that suggests whether going through such a painful and costly procedure is likely to do his client any good. A lawyer advising an interest group seeking judicial review of an administrative rule could learn a lot from studies of what is likely to happen,

29. For an excellent sample of this new work, see LABor LAW IN AMERICA: Historical AND CRITICAL Essays (Christopher L. Tomlins \& Andrew J. King eds., 1992).

30. See, e.g., Paul C. Weiler, Governing the WorkPlace (1990).

31. See, e.g., Katherine Van Wezel Stone, Labor and the Corporate Structure: Changing Conceptions and Emerging Possibilities, 55 U. CHI. L. REv. 73 (1988).

32. See, e.g., Jerry L. MAShaw \& David L. Harfst, The Struggle for Auto Safety (1990); Thomas O. MCGarity, ReInVEnting Rationality: THE Role of Regulatory ANALYSIS IN THE FEDERAL BUREAUCRACY (1991).

33. See, e.g., Philip Shuchman, Social Science Research on Bankruptcy, 43 RuTGERS L. REv. 185, 186 n.1, 189 n.10, 216 n.122 (1990) (reviewing TeRESA A. Sullivan ET AL., As We Forgive OUR Debtors: Bankruptcy and Consumer Credit IN AMERICA (1989)).

34. See, e.g., Mark Kelman, Concepts of Discrimination in "General Ability" Job Testing, 104 HARV. L. REV. 1157 (1991).

35. See, e.g., Vicki Schultz \& Stephen Petterson, Race, Gender, Work, and Choice: An Empirical Study of the Lack of Interest Defense in Title VII Cases Challenging Job Segregation, 59 U. CHI. L. REv. 1073 (1992).

36. See, e.g., Marc Galanter, Reading the Landscape of Disputes: What We Know and Don't Know (And Think We Know) About Our Allegedly Contentious and Litigious Society, 31 UCLA L. REv. 4 (1983).

37. See, e.g., Janet C. Alexander, Do the Merits Matter? A Study of Settlements in Securities Class Actions, 43 StAN. L. Rev. 497 (1991).

38. David C. Baldus et al., Equal Justice and the Death Penalty (1990).

39. Stanton Wheeler et al., Sitting in Judgment: The Sentencing of WhiteCollar Criminals (1988). 
or not happen, if the decision is remanded to the agency. A lawyer working on labor law reform legislation needs to know whether the approach she favors is likely to help or hurt the cause she supports. A lawyer representing a black defendant who is accused of a capital crime and is trying to choose between going to trial and copping a plea might want to know that, if convicted, his client is less likely to receive a death sentence if the murder victim was black. A judge drafting a remedial order might find it useful to learn that previous orders of the same kind have been wholly ineffectual. The many lawyers and politicians debating the "litigation explosion" could profit immensely from studies that - if they only paid attention to them - would tend to disabuse them of the widespread belief that tort plaintiffs are overwhelming the courts with frivolous and excessive claims.

Now I am not, I hope, a positivist naif. Empirical social study - I include history and ethnography - is never going to yield lawlike regularities that can make law practice into some sort of exact predictive science. Social science is a value-soaked, fuzzy, messy, dispute-riddled, political enterprise like any other interpretive activity - like law, for instance. But unless it is total hack work or ideological claptrap, the sketch maps it draws are better than nothing - and nothing about the actual workings of the legal system is what the traditional doctrinal education typically provides. If you were about to be posted as a diplomat to some foreign country, wouldn't you first want to read up on it - through histories, ethnographies, travelers' reports, statistical studies, literary accounts - even knowing that the actual experience of living and working there will eventually revise all the impressions you got from your reading? The reading gives you an orientation, a starting point, some categories through which to begin processing the experience. So if I had the power - which of course I do not except insofar as I can influence students who then go into law teaching - to redirect legal scholarship, I would use it to try to promote more empirical work, institutional description, and law-in-action studies. Sometimes I think I would happily trade a whole year's worth of the doctrinal output turned out regularly by smart law review editors and law teachers for a single solid piece describing how some court, agency, enforcement process, or legal transaction actually works. ${ }^{40}$

40. In areas like criminal law and procedure, where doctrinal work has retained a near monopoly of legal academic effort, the field is on the verge of becoming a wasteland because the doctrines, and the assumptions and categories underlying them, have so little connection with anything that is important to preventing or controlling crime or dealing with criminals. My colleague Robert Weisberg has made a powerful argument for irrigating the wasteland with insights drawn from scholarship in collateral fields like philosophy and, especially, criminology. 
My law school, for example, sends most of its graduates into largefirm corporate practice. We can and do teach them a lot of corporate law doctrine, and some economics as well. But in the present state of scholarship, none of us can give the students much of anything reliable to read that provides thorough, systematic descriptions and reflective analyses of what it is that corporate lawyers actually do, of the ways in which lawyers negotiate their work task and its boundaries with their clients and then translate client demands into work product, and of the strategic and ethical choices lawyers constantly have to make. ${ }^{41}$ There is certainly almost nothing written on a subject about which the organized bar, indeed any reflective practitioner, ought to know a lot - the likely social effects of different kinds of law practice. If we do not know - at a bit more demanding level of "knowing" than we can achieve from personal experience or hearing the stories our friends tell - what lawyers do, how can we evaluate whether it could be done better or is worth doing at all?

\section{Type \#4: “Critical”' Legal Scholarship}

Judge Edwards is especially severe on the category that includes critical legal studies (CLS), feminist theory, and critical race scholarship.

The CLS scholar does not demonstrate how authoritative texts constrain and guide a governmental decision. Rather, quite typically, the CLS scholar purports to "show" the opposite: that the texts are "indeterminate." This exercise is "impractical" because it seeks to show that the existing legal system is fundamentally flawed. At its best, CLS usefully

See Robert Weisberg, Criminal Law, Criminology, and the Small World of Legal Scholars, 63 U. Colo. L. Rev. 521 (1992).

41. There is very little as yet written about law firms that gives a good feel for how market and organizational structures, career patterns, professional self-images, firm cultures, financial pressures, patronage networks, and power hierarchies - running from clients to partners and partners to associates - condition how lawyers see their jobs, self-interest, loyalties, obligations, and practical moralities, and how these conceptions play out in their work. For a wonderful study of business corporations in this vein, see RoBert JACKALL, Moral Mazes: THE WORLD OF CORPORATE MANAGERS (1988). Fortunately legal sociologists have started to do first-rate work on law firms. See Marc Galanter \& Thomas Palay, Tournament of Lawyers (1991); Robert L. Nelson, Partners with Power: The Social Transformation of the LARGE LAW FIRM (1988); Symposium on the Law Firm as a Social Institution, 37 STAN. L. REV. 271 (1985); Symposium, The Growth of Large Law Firms and Its Effect on the Legal Profession and Legal Education, 64 IND. L.J. 423 (1989). Some very exciting studies of lawyer-client interactions have appeared. See, e.g., KenNeth MaNN, Defending White-Collar Crime (1985); William L.F. Felstiner \& Austin Sarat, Enactments of Power: Negotiating Reality and Responsibility in Lawyer-Client Interactions, 77 CoRNell L. REv. 1447 (1992); Austin Sarat \& William L.F. Felstiner, Lawyers and Legal Consciousness: Law Talk in the Divorce Lawyer's Office, 98 YALE L.J. 1663 (1989). Louis Auchincloss' novels may still be the best introduction to law firm culture, though most of them predate the present phase. See, e.g., Louis AuchinCLoss, A LAW for the Lion (1953); Louis AUchincloss, The PARTNers (1974); Louis AUCHINCLOSS, POWERS OF ATTORNEY (1963). 
questions and challenges the political premises that serve as the foundation of our system of justice; at its worst, CLS is hopelessly destructive because it aims to disrupt the accepted practice of judges, administrators and legislators with no prescriptions for reform. ${ }^{42}$

Edwards later adds that "[t]he nihilist scholar, who believes that texts are infinitely plastic and subjective, can only teach students to destroy legal texts, not to construct them."43 This picture of "critical" scholarship is wildly distorted, but its misconceptions are so widespread that they deserve more than a short answer. To begin, Judge Edwards' account seems contradictory: it tells us that a method pointing out fundamental flaws in the existing legal system is "impractical" by definition but then concedes such a gadfly function is "useful." I should think so, indeed: a radical critique of existing law is not invalid because it is radical, so long as it is true. If the legal system or aspects of it are in fact fundamentally flawed, the exposure of those flaws is a signal public service - regardless of whether the critic happens to have a basketful of remedies immediately at hand. One does not have to refrain from pointing out the house is burning before the fire brigade arrives.

Judge Edwards' critique here as elsewhere partly derives from his formalism and his judge-centeredness. To the extent judicial discourse remains formalist, lawyers must argue before courts as if existing doctrine constrains the legal solution they seek: they must say the "law" dictates the result they want even if they know perfectly well that it is consistent with a wide range of possible results - which is usually the case if the legal issues are seriously disputed. As I said earlier, just because judges and advocates are compelled by their roles to accept this fiction, I do not see why scholars should be. Other legal roles have fewer constraints. The constraints before administrators framing a rule or order de novo are not very strait ones due to the agency's usually rather broad and vague statutory delegation. Before legislatures the constraint of existing "authoritative texts" mostly disappears altogether: ${ }^{44}$ petitioners may and often do criticize existing law with abandon and recommend any revision they think sensible - within the very broad limits set by plausible constitutionality.

Anyway, Judge Edwards' view of the "practical" would seem to

42. Edwards, supra note 1, at 47 (citation omitted).

43. Id. at 59.

44. Judge Edwards points out that even the legislature needs pointers on doctrine, the "existing legal regime." Id. at 55. But he adds that it also needs to know how the law "has failed in the past," $i d$., and that "the "practical' scholar shows, inter alia, how the legal regime works," id. at 56, without noting the evident fact that only empirical, not doctrinal, inquiry can address some of the crucial questions. 
restrict scholars to recommending only those changes that current decisionmakers would be likely to accept, in the language that those decisionmakers like to use. Most scholars - in my view unfortunately - already accept these restrictions. But legal scholars have never tied themselves down to immediately realizable reforms, and they should not start now. For the first third of our century, Progressive scholars - and a few dissenting judges - kept on patiently plugging for social legislation and for constitutional law protecting dissident speech and expanding the powers of national government, programs that often had not a prayer of being accepted by a hostile judiciary. For the second third of the century, scholars like Fleming James and Friedrich Kessler kept arguing for programs such as expanded enterprise liability and no-fault auto accident plans that at the time had little or no support from any branch of government. In the 1980s, many scholars continued to argue for the justice and wisdom of expanding liberal programs such as affirmative action in the face of the resolute antagonism of the federal executive and, increasingly, the federal judiciary. So who, or what, is the audience for such arguments? In many instances the audience is not current officialdom at all, but social movements and public-interest groups who are trying to change the political agenda. For such movements, scholarship that documents the flaws in existing systems can be a very practical instrument indeed. 45

But let us return to Judge Edwards' main point against "critical" scholarship: that it "destroys" legal texts by showing their plasticity, without constructing anything positive. First of all, as I have already suggested, the view that legal texts are "indeterminate" in some sense is no invention of CLS, but has been shared by most of the dominant modes of antiformalist legal thought, from Holmes through the legal realists and their successors. In any first-year classroom in the country, one can find basic instruction in postrealist legal method, in which students learn how cases and statutes may be read broadly or narrowly: how the force of a precedent may be limited to its peculiar facts or expanded into a statement of broad principle; how a legal rule

45. Of course sometimes the audience for the most innovative scholarship is more diffuse still - what one might call the inchoate public conscience or as yet unformed public opinion. One of the functions of scholarship is to float out onto the airwaves modes of thinking about law and policy that are unfamiliar and unconventional, not now part of anybody's agenda, though they someday may be. I can see why this sort of work might be called "impractical." But when one looks at the origins of major changes in law and public policy, one often finds them in intellectual or theoretical movements that at the moment of their first utterances were neither welcomed nor comprehended. When Jeremy Bentham's views on the reform of evidence law were published in 1827, for example, see Jeremy Bentham, Rationale of Judicial Evidence, Specially Applied to ENGLish Practice (London, Hunt \& Clarke 1827), he was ridiculed and largely ignored. In recent decades his reform program has largely been adopted, and lawyers who have never heard of him accept his ideas as their conventional wisdom. 
may be read as a bright-line decisional rule or as an illustration of a broad standard; how a statute or constitutional clause may be construed by means of textual literalism or historical intentionalism, or dynamically as a charter of broad purposes whose applications will evolve over time and adapt to changing circumstances. Thus the view that the authoritative materials do not compel particular results but may support arguments for a range of results is inherent in utterly conventional, noncritical legal method. ${ }^{46}$ After demonstrating to his audience - his students or readers of his articles - various alternative readings of the doctrine, what should the law teacher do? One choice is to fall back on convention: "Most jurisdictions say X." Another is to try to identify some policy or value subtext that will resolve the ambiguity; or to identify some of the competing policies or values that might be "balanced" to resolve it - perhaps some trade-off of "efficiency" or "security of expectations" against "avoiding gross unfairness." 47

What do "critical" scholars do? We need not waste time on the charge that they believe that legal texts are "infinitely plastic and subjective," since no critical scholar has ever, anywhere, argued anything of the kind. One of the things they do is simply to amplify ordinary postrealist legal analysis into a more systematic method. They make inventories of the standard types of doctrinal and policy argument that are conventionally deployed in their legal fields. ${ }^{48}$ In contract law, to cite an example at random, one may construct the intentions of parties by using a formal "objective" test that standardizes meanings of terms across contexts, or by a very particularized inquiry into the parties' past and present dealings and trade customs. ${ }^{49}$ The usual policy reasons for choosing one method or the other are reasons like: "The for-

46. Just to clarify: To say this is not to deny that at any given time most cases are "easy cases" in the sense that most lawyers will be able correctly to predict the outcome. But that predictability is not somehow an inherent property of the legal texts: it results rather from the fact that authoritative readings of the texts have led, for the time being at least, to a relatively stable and widely shared conventional reading. That convention may, however, be "destabilized" by repeated challenges - or just by shifts in other doctrines or public or legal opinion that make it seem no longer plausible. For over 50 years, for example, conventional legal and public opinion supposed that the Equal Protection Clause of the Fourteenth Amendment was perfectly consistent with state-mandated racial segregation. Any lawyer who tried to argue otherwise was impatiently dismissed. When John W. Davis undertook to argue Brown v. Board of Educ., 347 U.S. 483 (1954), for the Southern states he assumed it was a slam-dunk, easy case. He was, of course, wrong by a zero to nine vote margin.

47. The teacher's balancing might not always be the same as the legal convention: "Most jurisdictions say X, but the "better view' is Y."

48. Incidentally - something that ought to please Judge Edwards - most "critical" teaching is intensively doctrinal. 1990).

49. See generally 2 E. AlLAN FARNSWORTH, CONTRACTS $\$ \S 7.9-10$, at 502-14 (3d ed. 
mal test ensures predictable and uniform outcomes in litigation and is cheap and easy to apply," "The informal inquiry is more likely to effectuate the actual intentions of the parties," and so on and so forth. Critical teachers have students practice making the typical doctrine and policy arguments, along with the typical counterarguments, in every case. The students see that the system has argumentative resources that present varying possibilities for the resolution of every legal issue. Legal and policy discourses are not determinate, but neither are they "infinitely plastic and subjective": they are highly constrained by the available stock - though creative lawyering of course may always expand that stock - of argument types coexisting in patterned oppositions. The opposing arguments often reflect deep conflicts between social visions: divergent views of efficiency, distributive fairness, the obligation we should have to look out for one another, and the meaning of "consent" under conditions of need or subordination.

The differences between this "critical" method and Judge Edwards' ideal education are instructive. Judge Edwards writes:

[A] doctrinal education is a crucial part of the lawyer's ethical development. The ethical lawyer should only advance reasonable interpretations of the authoritative texts - interpretations that are plausible from a public-regarding point of view. The ethical lawyer's brief should be reasonably true to those texts, and to the public values they embody. This is what law schools must teach, for it appears that law firms no longer can. The doctrinal capacity - the capacity to develop and communicate a true understanding of some legal regime - is a necessary condition for ethical practice..$^{50}$

There is much in this formulation to admire, especially as it amounts to a major qualification of Judge Edwards' formalist position though he steals a base over to formalism in the slide from "reasonable" and "plausible" into "true understanding." Here the judge recognizes that interpretations of the authoritative texts may vary, and that the choice among variations requires attentiveness to "public values" - that is, values of morality and policy. So far, so good: legal decisionmaking implicates questions of value and sound policy; lawyers should be aware of public values and promote them in their work of representing clients. The gap between Judge Edwards and the "critical scholars" opens with his implication that a "true" interpretation will yield a single correct answer. To the "critics" it seems awfully implausible that greatly contested issues of ethics and utility, in a pluralist polity whose groups and individuals pursue diverse and often

50. Edwards, supra note 1, at 59. 
incommensurable goods, should be capable of optimally correct resolution through the craft techniques of legal analysis. That is not a reason for refusing to try to resolve these issues, for lawyers and legal decisionmakers make value choices even when they try not to choose, as when they fall back upon prevailing conventional formulae and pretend they have no other option.

When the Judge says "critical" scholars do not try to "construct" legal texts, he must mean that they do not teach and write as if the doctrine, or rather the doctrine informed by attention to "public values," could yield uniquely correct answers. He is certainly right about that. Yet I confess I would think myself horribly incompetent at the purely "practical" job of training lawyers if I failed to show my students how to identify, and base arguments on, the many different types of doctrinal and policy reasoning that judges and lawyers employ every day: broad and narrow readings of precedent and statute; formal and informal methods of interpretation; variant strategies for constructing the intentions or capacity for foresight of criminals, testators, contracting parties, and tortfeasors; and different economic arguments - often, in fact, completely contradicting one another as one moves from one case or context to another - about what kinds of property rights, liability standards, or damage rules will deliver the right mixture of incentives to encourage optimal amounts of production or precaution. I teach the standard variations of and contradictory responses to the stock legal arguments largely because they exist out there in the world and practitioners make use of them. I did not make them up out of some fiendish motive to discredit the legal system. If I were a judge with a formalist conception that my role required suppressing what seem to me the obvious facts of variation and contradiction in legal discourse in order to make the doctrinal universe appear a (mostly) seamless and harmonious whole, I guess I would swallow hard and do it. But I am not. In fact I am happy, not at all upset, about the marvelous diversity of the doctrinal and policy universe of legal discourse, because it means that I can, in total good faith, teach my students that we are not all stuck with the current stock of conventional answers to legal questions. We can all find plenty of resources in perfectly ordinary modes of legal discourse to urge improvements on the existing legal constitution of society.

"Critical" scholars do recommend improvements all the time: I am always taken aback by the charge that they just trash the going system, that they are "nihilists" who tear down without trying to con- 
struct. ${ }^{51}$ I could illustrate this by citing almost any major piece of CLS, feminist, or critical race scholarship. I will limit myself to just one, an exemplary exercise in the CLS mode: Joseph Singer's article, The Reliance Interest in Property. ${ }^{52}$ Singer's piece is about a case in which the Youngstown local of the steelworkers union sought damages from U.S. Steel for closing down the plant where the local's members had worked.53 The steelworkers stated a claim based on "promissory estoppel" 54 that they had worked extra hard and given up concessions in reliance on the company's assurances that it would keep the plant open if its operations could be made profitable. The Sixth Circuit held the company not liable, as probably most courts in America would have done: the steelworkers' theory was just not on the map of existing conventional arguments in this context. Singer devotes the piece to showing that, despite the conventional wisdom of the legal system, the outcome was hardly inevitable or foreordained by the terms of legal discourse viewed from a larger perspective. He conducts an exhaustive review of legal and policy arguments commonly made in analogous areas of property, tort, and contract doctrine to show that the legal system often supports reliance-based claims very similar to those of the steelworkers. He then discusses and shows the weaknesses and problems of the policy arguments often made to dismiss such claims - or legislation to restrict closings - in plant-closing contexts like the one at issue. He shows that the arguments used to distinguish plant closings rest upon unexamined and unsupported ideological and empirical premises about the natural justice and economic efficiency of a "property right" in employers to close plants at will. He concludes by recommending recognition of employee reliance interests in these and many similar situations. Singer, in short, uses the standard doctrinal and policy resources of legal discourse itself to

51. Judge Edwards, I regret to say, cites no examples of the "nihilist" tendencies he deplores.

52. Joseph W. Singer, The Reliance Interest in Property, 40 STAN. L. REV. 611 (1988). Singer's title echoes, of course, one of the great articles of doctrinal scholarship: Lon L. Fuller \& William R. Perdue, Jr., The Reliance Interest in Contract Damages (pts. 1 \& 2), 46 YALE L.J. 52 , 373 (1936-1937). Fuller and Perdue's article would seem to break many of Judge Edwards' rules for "practical" scholarship. It cites a lot of cases, to be sure, but it is also heavily theoretical and interdisciplinary. Its subject is not hard cases but ordinary cases. It draws on a lot of Continental law and learning. It does not accept the law "as it is" - that is, as judges then expounded it. Rather, in a combination of classical (Type \#1) and realist (Type \#2) modes, it boldly proposes a total reconceptualization of the foundations of contract liability, from a promise-based to a tortlike reliance-based liability. It is also one of the most influential law review articles ever written, one that prompted major revisions in the way judges and the practicing bar routinely think about contract law. 1980).

53. Local 1330, United Steel Workers v. United States Steel Corp., 631 F.2d 1264 (6th Cir.

54. 631 F.2d at 1269. For a current statement of the doctrine of promissory estoppel, see RESTATEMENT (SECOND) OF CONTRACTS $\$ 90$ (1979). 
open up for reexamination and critique the current predictable, conventional wisdom of the legal system. He shows that what may at first seem like an unacceptably "radical" interpretation of law has deep roots in traditional legal norms and practices. In a political climate more favorable to labor than when the piece was written, 1988, Singer's piece would - and maybe will? - be a big help to the labor bar and to any legislature considering plant-closing legislation.

One more note - I promise, only one - about "critical" scholarship. Judge Edwards tells us that adherents of "law and" and "critical" movements have a "low regard" for the practice of law and that their "disdain" for practice leads them to produce impractical scholarship. Again he mentions no names or examples, so it is hard to know exactly whom or what he's talking about. But I do know this much: "critical" scholars are intensely interested in practice. As previously mentioned, they teach a lot of doctrine; they teach the critical methods of doctrinal and policy argument outlined above in part because they believe it is a valuable skills training; and they teach a lot of law and economics because they believe that students who do not know how to make, and see through, economic arguments will be disempowered in the real world of policy formation. In their law schools they can usually be found leading the fight — often alas against their traditionbound, doctrinally oriented colleagues - for more extensive clinical education. Most of them are active in practice themselves - as public interest advocates, clinical supervisors, legal ethics reformers and bar regulators, and advisors to legal services clinics. Above all, they have produced an extensive body of scholarship on law practice, much of it addressed specifically to lawyers already in practice or about to enter it. ${ }^{55}$ Of course the practices in which critical scholars are mostly interested are "progressive" practices - legal services, community organizing, lawyering for social movements or advocacy groups, civil rights, and civil liberties - but the last time I checked that type of law

55. See, e.g., Gerald P. Lopez, Rebellious Lawyering: ONe Chicano's Vision of Progressive LaW Practice (1992); LubaN, supra note 8; Abel, supra note 8; Ruth Buchanan \& Louise G. Trubek, Resistances and Possibilities: A Critical and Practical Look at Public Interest Lawyering, 19 N.Y.U. Rev. L. \& Soc. Change 687 (1992); Peter Gabel \& Paul Harris, Building Power and Breaking Images: Critical Legal Theory and the Practice of Law, 11 N.Y.U. REV. L. \& SOC. Change 369 (1982-1983); Duncan Kennedy, The Effect of the Warranty of Habitability on Low Income Housing: "Milking" and Class Violence, 15 FLA. ST. U. L. REV. 485 (1987); Carrie Menkel-Meadow, The Legacy of Clinical Education: Theories About Lawyering, 29 ClEv. ST. L. REV. 555 (1980); Carrie Menkel-Meadow, Toward Another View of Negotiation: The Structure of Power Solving, 31 UCLA L. REv. 754 (1984); Simon, Visions, supra note 8; Symposium, Theoretics of Practice: The Integration of Progressive Thought and Action, 43 HASTINGS L.J. 717 (1992); Louise G. Trubek, Critical Lawyering: Toward a New Public Interest Practice, 1 B.U. PUB. INT. L.J. 49 (1991); Lucie White, Representing "The Real Deal," 45 U. MiAMI L. REV. 271 (1990); Wilkins, Legal Realism for Lawyers, supra note 8. 
practice was as real as any other. Moreover, some critical scholars write about business-law practice as well. The bottom line is: "critical" scholars are as practically oriented as any, and more than most. Judge Edwards should be embracing them as allies.

\section{Type \#5: Theory}

Judge Edwards is pretty skeptical about "theoretical" legal scholarship, though he thinks there is a useful function for theory in helping to resolve "hard cases" in the fringe areas. He is also willing to tolerate some role for it in scholarship and teaching, even though he believes that role has grown too relatively large. The lawyers in his survey sample are more robustly antiintellectual, some drawing a firm line between "theoretical" and "practical" work and dismissing the former as utterly useless.

I will not try to make an extended case for the practical value of theory. The whole "theory-practice" distinction strikes me as unutterably daffy. The point of theory is to clarify and inform practice: if it does not, it is just bad theory. As Holmes put it:

Theory is the most important part of the dogma of the law, as the architect is the most important man who takes part in the building of a house. The most important improvements in the last twenty-five years are improvements in theory. It is not to be feared as unpractical, for, to the competent, it simply means going to the bottom of the subject. ${ }^{56}$

Of course there are many aspects of law practice, like all other social practices, that are neither readily theorized or susceptible to being learned via theoretical approaches. Much of law practice is like a language, or a craft skill like (to use Stanley Fish's example ${ }^{57}$ ) Dennis Martinez's pitching ability: the only way to learn it is through practice, on the job, as an apprentice to someone who does it well. Just as much practice cannot be theorized, much academic theory is surely useless to practitioners. ${ }^{58} \mathrm{I}$ hardly count theory as useless, however, if

56. Holmes, supra note 13 , at 200-01.

57. Stanley Fish, Dennis Martinez and the Uses of Theory, 96 YALE L.J. 1773 (1987).

58. Since I have reproached Judge Edwards for not giving examples of the trends he deplores, I should mention some types of theory that one can find in today's law reviews that strike me as, if not always useless, not very useful. With hesitation then, and fearfully assuming the risk that defenders of these types of work will undoubtedly find me an arrogant, prejudiced, ignorant lout, here is my list: public choice theory; hyperformal economic models of optimal liability and damage regimes; almost the entire "efficiency of the common law" literature; Bayesian approaches to nonstatistical evidence; most legal applications of sociobiology; narratives of the "authentic experience" of subordinated peoples not actually drawn from relations or ethnographies of any of those peoples; total systems of legal rights constructed from first principles of purportedly natural law; jurisprudential literatures asking "What is Law?"; highly abstract general theories of the legal process - for example, of the ideal relationship between courts and legislatures unconnected to any historical experience of actual courts and actual legislatures; purportedly historical interpretations of legal texts for modern use that ignore all intervening 
it helps one understand social reality, even if it does not also help one manipulate it. After all, making sense of social life and finding meaning in the human condition is in itself a practical, instrumental activity, one into which all cultures pour a lot of effort and imagination in the course of their development, long before they discover the delights of making money.

But although some law practices may be theory-resistant, and some legal theory irrelevant to any conceivable legal practice, law as it is actually and ordinarily practiced is loaded with theoretical assertions and preconceptions. It uses highly abstract models of the world that structure perceptions, frame conceptions of legal and factual problems and their appropriate resolution, and help explain and justify the world and what lawyers do in it. Sometimes these models are inarticulate or semiarticulate; but quite often - because one of our profession's basic operational modes is after all rational argument and justification - they are out in the open, and at least lightly intellectualized. Sometimes indeed one can trace directly the theoretical presuppositions of practitioners - whether or not the practitioners themselves are aware of this fact - to some more formal body of theory originally developed by intellectuals. ${ }^{59}$

Moreover, law is a profession whose own norms require it periodically to reform and refresh its practices through theoretically selfaware critique. That is, the critical scrutiny of what lawyers do, the attempt to find a basis in principle for what they do, and the reform of the practices to conform more closely to the principles are all intrinsic to the practice of law itself. For this reason I think that accounts of legal practices that distinguish too sharply between perspectives that are "internal" to the profession, such as those of the practitioner or judge, and perspectives that are "external," such as those of the anthropologist, are overdrawn. The external perspectives may be and

history between the text's enactment and the present; purely doctrinal approaches to legal fields, such as criminal procedure, in whose actual administration doctrine plays a very small part; many articles with extensive cites to the work of Jacques Derrida or making extensive use of "postmodern" as a descriptive or explanatory category; and more generally any other theoretical approaches that seem neither to be built out of nor to have any plausible application to the way human beings think and act and the way legal, social, and political institutions function. I am willing to be talked out of any of these prejudices, if anyone wants to bother to try.

59. This link between inarticulate legal premise and theory is most obvious in the case of economic theory. The doctrine of the late nineteenth-century "classical" period in a great many fields - the law of competition and combination, labor law, public utilities, taxation, and constitutional limitations - was soaked in preconceptions derived from classical economic theory. In the first decades of our century, these legal doctrines were modified to reflect the growing infuence of marginalist theory and institutional economics. See generally Herbert HovenKAMP, ENTERPRISE AND AMERICAN LAW, 1836-1937 (1991). In our own time of course, neoclassical economic theory has colonized whole provinces of the legal system. See supra notes 26-27 and accompanying text. 
often are instrumental to the internal projects of self-understanding and reform.

What follows from adopting this view? What follows is an idealized view of the appropriate partnership between the bar and the schools. The academics would (1) look at what the lawyers do, (2) float to the surface the sunken theoretical and empirical suppositions of lawyers' practices, (3) restate those suppositions in elegant and wellorganized forms, (4) examine them critically in terms of whatever legal and nonlegal perspectives - legal science, social science, history, political theory, feminist theory, literary theory, ethics - seem to shed any light, (5) generate prescriptions for reform, or reasons why reform will not work, ${ }^{60}$ and finally - only of course if this is feasible, if the reform ideas have reached the stage of potential practical adoption (6) form alliances with reformers - bar groups, judges, policy institutes, public interest advocates, social movements, and legislators to translate the ideas into action. Lawyers and officials would then experiment with the new ideas in their practices, and the cycle would begin anew.

\section{FISSURES IN THE MidDLE GROUND}

This sunny and rational scheme for dividing professional labor would take maximum advantage of the scholars' comparative advantage. They are not usually so highly specialized as lawyers, at least corporate lawyers, have to be these days. They are not in so much of a hurry. They can take the time to locate a legal rule, such as a section of the tax code, in the overall structure of the tax law and its overarching principles and economic purposes. They can compare it with practices in other legal cultures and put it in historical perspective. Because they are part of a university, have access to colleagues in other fields and increasingly have some interdisciplinary training themselves, they can use the theories and methods of other disciplines to help restate and evaluate the hidden nonlegal agenda of the legal system, its ideological, economic, empirical, and ethical premises. They can also design and carry out studies assessing the system's social effects. What they lack in actual experience of practice they can partially compensate for in detachment. Because they have the luxury of not having to please clients or to depend on current modes of prac-

60. I add this caveat because sometimes the academic contribution may take the very useful form of suggesting that, although the existing practice is theoretically incoherent and practically flawed because it has many unfortunate side effects, it is a tolerable second-best solution, and attempts to change it are likely to make matters even worse. The academics may also conclude that the flawed practice is the result of long-term environmental conditions beyond the capacity of any reform agency to alter in any significant way. 
tice to make a living, they can be critical and reformist. The five types of scholarship outlined above would seem on the whole to meet the demands of the utopian vision. That is, they both nicely exploit the comparative advantage of legal scholars and supply advice that is, in the broad ways that I have outlined, "practical" to actors in the legal system.

What then has gone wrong? Why have judges and lawyers like Judge Edwards and his survey sample become so sour about legal scholarship? Why do they see such wide rifts and gullies opening up on what should be the tranquil and cooperative "middle ground" shared between scholars and practitioners?

Judge Edwards' answer, as we have seen, is that the scholars have wandered off the middle ground by abandoning, or at least deemphasizing, the exposition of doctrine and doctrinal education, choosing instead to do theoretical, interdisciplinary, and critical work of little or no "practical" value to the profession. They have done this because, increasingly lacking in practice experience themselves, they "disdain" and have a "low regard" for the practice of law and therefore for work that helps practitioners; they do the kind of work that the university rather than the bar is likely to value and reward. Is the answer plausible?

\section{A. First of all, is the answer factually accurate?}

Are legal scholars producing less doctrine? Ariela Gross searched at my request the contents of three major law reviews ${ }^{61}$ in 1910 and every tenth year thereafter, to sense historical trends; and of five major law reviews ${ }^{62}$ in the last five years, to sense current trends. What she found is very interesting. ${ }^{63}$ As one might expect, the share of total

61. COLUM. L. REV., HaRV. L. REV., YALE L.J.

62. Colum. L. Rev., HaRv. L. Rev., Stan. L. Rev., U. Chi. L. Rev., Yale L.J.

63. Ariela Gross's research report summarizes her findings as follows: Several things are evident from this survey of the contents of ninety years of law reviews: 1) the majority of the pages of a law review have always been, and continue to be, devoted to doctrinal analysis, or, as Judge Edwards would have it, "the law"; 2) a substantial portion of law review articles have always been devoted to "theory," politics, history, or legal education.

The most obvious changes have been away from Langdellian categories of law - such as "telegraph companies," or "oil and gas." But this trend began in the 1930s, and it is hardly a cause for contemporary alarm. Substantively, articles have shifted away from common law topics and towards administrative law, public policy, corporate law, criminal procedure, labor law, and constitutional law. The Yale Law Journal has been particularly heavy with constitutional theory in the past several decades. But this emphasis also reflects shifts in legal practice, as well as public attention to the Warren Court and its legacy. It is not what Judge Edwards discusses.

The article on a fairly specific topic - which either discovers a pattern in case law, or summarizes the trends in legal doctrines and then suggests where the future lies or proposes reforms - is something of a historical constant. However, it is true that in the years between 1930 and 1960 this type of article was predominant in the law review, filling one-half to two-thirds of its 
contents taken up by doctrinal articles - defined here simply as articles that discuss a specific case, cases interpreting a statute, or a field of law with a lot of cases cited - was highest in 1910. From then until now, doctrinal articles make up the clear majority of contents. The relative share of doctrine does dip slightly beginning in the $1920 \mathrm{~s}$, losing ground to pieces on theory, jurisprudence, and current issues of public policy. Doctrine's share is lowest, interestingly, around 1950, rising somewhat in 1980 and 1990 . Within the doctrine category, "narrow doctrine," the piece devoted to a very specific case or legal issue, tends to predominate over "broad doctrine," the piece analyzing broad categories of doctrine, until recent years. In the 1988-1992 sample, narrow and broad doctrine have about equal shares. Theoretical or interdisciplinary articles with few or even no case citations were common in the 1920s and 1930s - the height of the realist controversy. These types of articles have become still more common in the last five years, averaging about six pieces per law review per year. The share of history has remained both low - about two or three pieces, five to ten percent, per review per year - and constant over the whole period.

Our little sample is hardly scientific, and we could argue about its method forever - which is why I am not bothering to describe it in more than summary detail - but still it is better than a total vacuum. What does it tell us? That doctrine is still the staple commodity, even in the reviews edited at fancy schools that go in for the fancy new stuff. Because the total number of law reviews has grown enormously, especially after the big expansion of law schools, and hence law reviews, in

pages. Yet, in years when there have been fewer narrow doctrinal articles, it was usually not abstruse, theoretical articles that pushed them out, but broader, thematic articles, about "the law." While these articles have changed a great deal over the century, from Beale's treatise chapter on contracts to broad discussions of administrative agencies to school desegregation, the goal is still to give an overview of a whole area of legal practice, critique it, and suggest paths for the future. Thus, while the 1990 Columbia Law Review has only four out of eighteen narrow doctrinal articles, seven more articles were broad overviews of substantive legal areas.

As for "theory," it has been alive and well for decades. While the Harvard Law Review did not let much sneak in until 1960 or so, Columbia in 1920 and 1930, and Yale in 1910, 1920, 1940, and 1950 have a large number of articles by proponents of sociological jurisprudence, legal realism, and traditional legal science, as well as articles on completely "political" issues with almost no "law" at all.

Also notable is the extent to which the category of "theory" has not "infected" the category of doctrinal analysis. For example, the 1990 Yale Law Journal has an equal number of articles on such theoretical topics as "community in constitutional theory," and "the Coase theorem" as it does articles on "filling gaps in contracts" and "qui tam." The doctrinal articles do not appear to take a conscious theoretical perspective, although that is not true of all law review articles that focus on a particular area of law. The broader overviews of doctrine are much more likely to state a viewpoint or theoretical framework, usually on a constitutional topic - in this issue, affirmative action and sexual harassment (Title VII). In general, though, there is a surprising paucity of articles that identified themselves as being "CLS," "critical race," "feminist" or any of the other dread schools against which Judge Edwards inveighs. 
the 1970s and the growth thereafter of multiple journals at a single school, the absolute volume of total doctrinal output must be far vaster in 1993 than it has ever been. How much doctrine, one has to wonder, does the bar want? Judge Edwards is certainly right, however, that doctrine has to share the stage with other types of work, and that a modest proportion - about fifteen percent is my informal estimate - of total scholarly output is now devoted to theory and "law and" work, incidentally much more usually non-"critical" than "critical" work (the latter is rare in our sample), which cites few or no cases. The other main nondoctrinal category is that of pieces on current political and public policy issues. In our sample at least, there is not a single piece that does not have something to do with law or legal institutions or policy.

Is use by lawyers, including judges, legislators, administrators, public interest lawyers, policy analysts, and advocates - of legal scholarship declining? I cannot even begin to guess the answer. Judge Edwards says "Yes," but the studies cited in his own footnotes do not entirely support him. A very recent Stanford Law Review study of citation practices found that judges and practitioners as well as professors continue to read law reviews, though chiefly for the purpose of tracking current developments in their practice specialties. While not giving them rave notices, they believe that law reviews are moderately successful at meeting their goals. ${ }^{64}$ Judge Edwards' own survey method has some serious problems. Law practice is now very specialized. A lawyer may spend all his time, even his career, representing clients before a single agency, or advising them on four or five sections of the tax code. Such a lawyer is obviously hardly ever going to find articles in any general-purpose law review that bear immediately on specific problems in his or her specialty. Instead, he or she will have to go to specialized law reviews, in which most of the contributors are practitioners, or officials, in his or her specialty, along with the occasional academic. A fairer and more revealing survey method might be to look at the current contents of a law review to try to identify, or ask the author to identify, the potential practitioner or policy audience for each of the articles, including even the very "theoretical" ones; and then to ask lawyers or policy wonks from the targeted audience to read the piece and ask if they learned anything from it.

64. Max Stier et al., Law Review Usage and Suggestions for Improvement: A Survey of Attorneys, Professors, and Judges, 44 STAN. L. Rev. 1467 (1992). Though, like Judge Edwards, the practitioner-respondents to this survey want less "theory" than they get, they would like more "empirical" work. Id. at 1498. 
B. Assuming the truth of Judge Edwards' unproved thesis, why don't practitioners want to read our stuff - especially our theory, "law and" (interdisciplinary), or "critical" stuff?

Judge Edwards says it is because we "disdain" them and do not want to write for them; we write for each other and for the rest of the university instead and award each other recognition and tenure by academic rather than professional standards. Is that right?

This assertion is clearly not entirely wrong. The judge has a legitimate beef about the reader-unfriendliness of many law review articles. Sometimes they seem written for no one's consumption, unless perhaps an alien's or a computer's. Like judicial opinions, they have become unbearably long. In the great iconoclastic period of American legal scholarship, the 1920s and 1930s, article writers said what they needed to say in ten to thirty pages and then stopped. There is also undoubtedly a fringe - at an informal guess, a widening fringe - of articles showing signs of infestation by scholastic diseases: jargon-laden, ingrown, self-referential quarrels within a narrowing clique. These problems are serious. Some of our colleagues are in danger of writing their way out of any readership save their friends and their tenure committees.

Some of these vices, however, derive from our scholarly conventions of trying to write for generalist rather than specialist audiences. Current articles are long and dull in part because their writers assume no background knowledge in their readers. ${ }^{65}$ Everything, from the doctrinal and historical context to the meaning of elementary terms of economic or critical analysis, has to be elaborately spelled out. That is not how any real academic discipline operates. Legal scholars do not have enough places where they can carry on internal conversations in scholarly shorthand. ${ }^{66}$ Their enterprise has grown ungainly, partly from trying to address too many constituencies at once.

Yet clearly the most important of those constituencies remain the managers of the legal system - judges, lawyers, legislators, administrators, policy and advocacy groups, social movements, and so forth. To this day the overwhelming bulk of what appears in the law reviews

65. Judge Edwards' ideal product, doctrine-for-practitioners, would in today's practice conditions have to be highly specialized. No one article would be accessible or interesting to more than a handful of readers. But at least it could take those readers' knowledge for granted.

66. The peer-review edited scholarly journals such as the Journal of Legal Studies, Journal of Law \& Economics, Law \& Society Review, Legal History Review, and so forth perform this function to some extent. If there were more such journals, scholars might use them more regularly for their academic conversations and save the regular law reviews for communication to generalist and professional audiences. 
is the same as it ever was, what Judge Edwards calls "prescriptive" scholarship, scholarship that makes a normative argument to some set of hypothesized legal decisionmakers to analyze and address some legal problem in the recommended way. Law review articles are, basically, briefs. Even scholarship at the "meta"-level, concerned with issues of theory and methodology, is mostly concerned to ask whether we are going about this brief-writing enterprise the right way, using the right tools of analysis, reasoning modes, values, and models of empirical reality. Think, for example, of all the articles on whether judges interpreting the Constitution should rely on the framers' or ratifiers' original intent. It makes no sense to write prescriptively unless one has some audience of practical actors in mind.

Is the law review writers" attitude one of "disdain" or "low regard" for the practical world that must carry out their plans? ${ }^{67}$ On the contrary, it is affectingly, even heartbreakingly, idealistic about that world. The articles address a bench, bar, and officialdom that are by hypothesis incredibly cosmopolitan, reflective, and high-minded. They assume these hypothetical readers are keenly interested in understanding their practices and their conceptual and historical bases, in refining their empirical and value premises and analytic tools, in exploring the possible bearings on their work of the latest insights from other fields, in increasing the effectiveness of their work in serving valued social purposes; that they are deeply committed to reforming the legal system, including if necessary their own practices, to the ends of making it serve those purposes more efficiently and more justly. The scholars seem to be writing for a society of practitioners with the renaissance erudition of Oliver Wendell Holmes; the eagerness to learn from other disciplines of Jerome Frank, Richard Posner, or Ruth Ginsburg; the historical depth of Leon Higginbotham; the public in-

67. Judge Edwards and his sample, see Edwards, supra note 1, at 61 n.73, infer generalized "disdain" for the practicing profession from some law teachers' rhetorical use of adjectives like "ridiculous" to describe examples of judicial or other real world legal practices. This is, of course, the standard defense mechanism of intellectual lawyers against the practicing profession: "They may have more money and power and macho real-world experience, but we are better at legal reasoning." It is the exact counterpart to the ways in which practitioners speak of academics as "impractical," "ivory-tower intellectuals," "theorists who couldn't function in the real world." Such antagonisms are commonplace between the intellectual and practicing branches of any profession. In law, the antagonism begins after the first term of law school, when bright students with fragile egos often feel inadequate and sometimes humiliated for the first time in their lives, if not by Socratic bullying, by the way they have been graded. Some of this antagonism is inevitable; some could be avoided I think by restructuring legal education around a collaborative-clinical model of learning rather than a hierarchical sorting-and-ranking model. The trouble is, the law firms want us to sort and rank.

If Judge Edwards wants to hear really disdainful talk about lawyers and judges, he should drop by the bar nearest the courthouse. Nobody is more cynical about the legal profession than practicing lawyers. 
terest practice ideals of Louis Brandeis or Charles Evans Hughes; the doctrinal inventiveness of Benjamin Cardozo, Roger Traynor, or Shirley Abrahamson; the patrician reformism of Henry Stimson or Francis Biddle; the intimate involvement in policy formation of Lloyd Garrison or David Lilienthal; and the passion for social justice of Thurgood Marshall or Marian Wright Edelman. The lawyers they address are modernized versions of the lawyerly ideal that prevailed in our founding period: the republican - or Ciceronian - lawyer-statesmen, well schooled in history, political economy, and belles lettres; expert advisors on legal science to the bench and on legislative science to the legislatures; and active in public causes, periodically on leave from practice to public service. ${ }^{68}$ No real lawyer, of course, could possibly live up to every aspect of this ideal; though I know personally many lawyers who come close on several dimensions, and I know by hearsay and historical research of many more. But I doubt that anyone will dispute that such lawyers are rare and, perhaps, in the current state of practice, getting rarer. The point is that if most practitioners came anywhere near the idealized view that legal scholarship assumes of them, the practical relevance of that scholarship to their work would be unmistakable - in all the ways I tried laboriously to demonstrate above. ${ }^{69}$

In fact I sometimes think that most legal academics - along with judges, enforcement officials, retiring law firm partners in the old-fashioned lawyer-statesman mold, and social movement or public interest lawyers - are among the few people left in their profession who take law seriously, who believe that, for all the many flaws in its administration, the legal system embodies values and social purposes that deserve respect; and who therefore devote themselves with something very like piety to its ethical rationalization and improvement. A lot of practicing lawyers, on the other hand - though by no means all, for as Judge Edwards notes there is a huge reservoir of repressed idealism in the practicing profession - seem to regard law purely instrumentally, as a set of mechanisms and obstacles to manipulate strategically and to work around for the benefit of clients, or as a game to be played for the sheer thrill of winning. ${ }^{70}$ I certainly do not mean to suggest

68. For an excellent account of the ideal in its early republican form, see ROBERT A. FERGUSON, LAW AND LeTters iN AMERICAN CultuRE (1984).

69. See supra text accompanying notes 67-68.

70. One of the rather disturbing findings of the Stanford survey of law review use was that a very low number, $11.6 \%$, of the practicing lawyers ranked "To Evaluate the Effectiveness of Existing Law or Alternatives" as their first or second objective in reading law reviews. Almost two-thirds of the attorneys, $65.3 \%$, did not rank that objective at all. Steir et al., supra note 64 , at 1486 . I do not know whether these numbers better reflect the attorneys' lack of interest in how 
that law teachers are immune from the ordinary motives of self-interest and the distractions and corruptions of careerism: every occupation has its pathologies. But the dominant tone of scholarship is one of earnest high-mindedness about the legal system, a sustained and rather mystifying optimism. If anything, in my view, it is all much too soft-edged and sunny, far too sparing of the dark and bitter realities of legal institutions and the social worlds in which they work.

Judge Edwards' own article suggests an alternative set of explanations for the indifference of practitioners - still assuming, which we do not know for sure, that they are indifferent - to legal scholarship: namely, that lawyers these days are so harried and overworked, so specialized, so intent on hustling for and pleasing clients and watching the bottom line, that they have no time or inclination for any activity that does not seem immediately convertible to potential profits.

Much of what legal scholars do, and should do, is therefore not likely to be of much help to lawyers thus preoccupied. ${ }^{71}$ Scholars aim to make structural connections across practice specialties and doctrinal categories, for example to show the commonalities of tort, contract, property, competition, and labor rules. They aim to understand the structural and historical determinants of legal policies and practices, to understand how these came to be the way they are. Firm lawyers operating on little sleep and meeting close deadlines have no time for that. Scholars inspired by the intellectual goals of simplicity and elegance often try to reshuffle standard legal categories to meet those goals. Lawyers who have invested years of craft experience in learning the messy old categories will resist such changes. One of the main roles of scholars is to use their leisure and independence in the service of critique and reform of ongoing practices. Lawyers who make their living or gain strategic advantages from those practices will actively oppose proposals that may end up abolishing their sources of livelihood altogether. Scholars often work at trying to make more effective the public purposes expressed in regulatory legislation - fighting discrimination, augmenting the countervailing power of labor, attacking monopoly, increasing competition, protecting nonrenewable resources, promoting employment or old-age security, and redistributing wealth. It is not hard to see why lawyers who represent regulated constituencies with opposing interests and who have gradually soaked up the views of their corporate clients, will not welcome this

well the legal system works or the law reviews' failure to say anything interesting on that subject. In either case, something is amiss here.

71. See, e.g., Edwards, supra note 1, at 73: "Law firms have no right to complain that law graduates are 'unskilled,' where those skills are simply used to maximize profit." 
kind of scholarship. ${ }^{72}$

One does not have to be "disdainful" of or cynical about law practice to recognize these obvious facts. It is no secret that the elite bar these days is experiencing something of a crisis of morale and selfesteem. Distinguished commissions of the American Bar Association worry about its commercialization and declension from ideals of public service. ${ }^{73}$ Judge Edwards himself has some very harsh words to say about the current state of practice - that lawyers increasingly distort facts and law, engage in strategic manipulation of procedure, neglect public obligations, and are obsessed with making money. ${ }^{74}$ This situation is not some inexplicable outbreak of moral failure: it has structural causes, largely in the increased competition that rising corporate legal costs have promoted among firms. But it hardly promotes the formation of a bar elite capable of serving as the idealized audience for the intellectual insights and normative aims that legal scholars are best equipped to produce.

Indeed, I speculate that some legal scholars have in recent years begun to turn inward, to produce a more academic and self-referential scholarship, and to experiment with postmodern modes far removed in tone and spirit from the high-minded reformism of most prescriptive argument, precisely because they guess that they are losing their practitioner audience - to the extent that they ever had one. ${ }^{75}$ Some scholars are saying, "Well, if you won't try to understand us, we'll fix it so you can't." Some, of course, have lost confidence in the Enlightenment rational-understanding-leads-to-reform project altogether. There is a fascinating recent literature - a sort of counterpart literature from the scholars' side to Judge Edwards' polemic - on the problem of the audience for our work, doubting whether prescriptive legal scholarship, on which we spend most of our time - and on which the judge thinks we should spend almost all our time - does any good for anyone. ${ }^{76}$

72. One could argue that elite lawyers organized in large metropolitan law firms destroyed their own capacity to serve the public service ideals of the profession quite early in our history, when they made the fateful decision that they would exclusively represent the interests of one particular faction of civil society: big business interests. Louis Brandeis, Woodrow Wilson, Harlan Fiske Stone, and A.A. Berle are among the most eminent lawyers who have come to this conclusion. For a lengthy description of the argument and its bases, see Gordon, Corporate Law Practice, supra note 8.

73. See american Bar Assn. Commn. on Professionalism, “... In the Spirit of PUBlic SERVICE": A BLUEPRINT FOR THE REKINDLING OF LAWYER PROFESSIONALISM (1986) (Stanley Commission Report).

74. Edwards, supra note 1, at 66-74.

75. The practitioners' complaint about legal scholars as unworldly, hypertheoretical airheads is an ancient genre.

76. See, e.g., Pierre Schlag, Normative and Nowhere to Go, 43 STAN. L. REv. 167 (1990). 
Yet much of the inward-turning trend has been simply a function of the politics of the 1980s. Legal academics are mostly pretty liberal in politics. From 1980 to 1992, doctrinaire conservatives dominated federal executive policymaking. The Congress was passive and in disarray, unreceptive to new policy initiatives. The federal courts were increasingly conservative too. When one has little hope of influencing anybody in power, one's work is likely to turn critical, theoretical, and historical. Much of the concrete prescriptive work in this period was turned out by conservative law-and-economics scholars who could be confident there was a policy audience for it. ${ }^{77}$ I would predict that, during the Clinton years, many more scholars will be doing "policy" - articles on health care and tort reform, labor policy, tax policy, international trade, and urban policy. Public and private law doctrine - though still the staple of our work - will be revitalized if ever judges come to seem, once again, sympathetic listeners.

\section{If the diagnosis of disturbances of the "middle ground" just offered is correct, or nearly so, what is the remedy?}

Here I believe Judge Edwards lets us down badly: the remedy, he says, is more doctrinal education, especially teaching of the "reasonable," "ethical," and "true" interpretations of authoritative texts. ${ }^{78}$ This education is what students want; it is what the bar needs.

First a word or two on the legal education points of Judge Edwards' argument. Most law students, like some of the alumni Judge Edwards cites in his survey sample, ${ }^{79}$ always want more "doctrinal" education, though their view of doctrine is not the same as the Judge's. What they want is more "black-letter" law - that is, clear and wellorganized presentations of rules in the style of the well-taught bar review cram course. This "doctrinal" education we do not need. ${ }^{80}$ It

77. Compare some earlier periods. In the 1920 s and 1930 s, liberal scholars who wrote about constitutional law spent most of their time slashing and ridiculing the judicial product. They wrote off most of the elite corporate bar as hopelessly unreceptive to their policy ideas. They targeted their "practical" stuff - concrete, constructive, policy-oriented scholarship - to the lawyers they thought would listen, Progressive reformers and, ultimately, New Dealers. Indeed they wrote a lot of the New Deal legislation. In the 1960s and 1970s, on the other hand, legal scholarship was often "creative" doctrinal scholarship - in both public and private law. Common law courts were expanding contract and tort enterprise liability; constitutional courts were multiplying new rights. There was an easy symbiosis among the academy, activist courts, and social movements, as there had been among realist scholars, Progressive, and New Deal reformers.

78. See Edwards, supra note 1, at 57-66.

79. See, e.g., id. at 60 n.71.

80. I should qualify: some legal subjects are probably most efficiently taught through simple transmission, perhaps via programmed learning, of doctrinal rules. Such subjects are now taught very inefficiently by the case method, in which the rules have to be laboriously extracted and refined from a mass of detail in the cases. 
takes all the patience and care law teachers possess to try to show students that just learning rules is of limited use; that one has to learn also how to select the right rule for a case among conflicting rules, to apply rules to facts, to interpret rules and factual narratives and to argue contrary interpretations; and that these skills in turn require some grasp of principles, policies, and the importance of contextual variation. I have found over the years that a teacher can indeed move students away and above the black-letter law and to recognize the importance of theory, social context, and policy, so long as she does so in the setting of concrete case situations. ${ }^{81}$ In those situations students can readily grasp that the mere statement of applicable rules is inadequate to solve any legal problem complex enough to be the subject of dispute.

Judge Edwards says that legal education does not do enough to teach certain practical skills. I agree wholeheartedly. But I do not think teaching doctrinal reasoning is one of those deficiencies; we do more of that than anything else. Our casebooks are still even more overwhelmingly doctrinal than our scholarship; and by the end of the first year, with the help of moot courts, most students get quite good at massaging doctrine. My list of the skills they do not develop would include: working with statutes, administrative rules, and other noncase materials; working with messy and complicated factual records; drafting legal instruments like contracts, settlement agreements, opinion letters, and informal letters to clients; making sustained, as opposed to two- or three-sentence, policy arguments supported by empirical data; making normative arguments based on open-ended cri-

81. For reasons $I$ have never understood, students who were entircly capable of sustained abstract thought in college lose most of that capacity in law school. The minute that a teacher launches a discussion of theory, policy, ethics, or social context that is not immediately and closely tied to resolving a case situation, most of the students tune out and put down their pens. They know, of course, that they will only be examined on the cases and the principles and policies extracted from the cases. By the way, this classroom reaction, which every teacher I know experiences as intensely frustrating, ought to please Judge Edwards. For it means that the "theoretical" orientation of legal scholarship does not percolate down very much into the classroom: most students just ignore it. My impression is confirmed by a recent study of Harvard Law students. See generally Robert GRANField, MaKing Elite LaWYers (1992).

I imagine this phenomenon has something to do with students' developing conceptions of professional identity, which relegate all nondoctrinal material to the realm of the "impractical." But where, and from whom, do students learn to do that? Interestingly enough, in recent years I have found that it is often my conservative students, the members of the Federalist Society, who have been most immune from the deadly virus - of which even Judge Edwards has caught a strain - that spreads the distinction between the "intellectual" and the "practical." The Federalists seem totally aware of the practical utility of building a worldview out of history, political theory, and economics, and legal theory that in turn will inform their views of practice and their reform agenda as lawyers. By contrast some of my more left-wing students, to my considerable distress, refuse to see how useful theory could be to their causes, reject it as elitist garbage, and view anecdote, autobiography, and polemic as sufficient substitutes. 
teria of justice, morality, and fairness; and acquiring a working knowledge of how legal institutions actually operate, not just in formal supposition but in fact. 82

In other words, the narrow doctrinalism of law students is something we have to keep struggling against. That struggle is best done in highly specific exercises, such as problem-method teaching through thickly described cases - like Harvard Business School cases, not appellate cases - and in clinical settings. ${ }^{83}$

For what he perceives to be the deplorable ethical condition of the practicing bar, the Judge's remedy is exactly the same: more doctrinal teaching - informed, naturally, by more doctrinal scholarship - in the law schools! This is a bit like trying to clean up the Augean stables with a teaspoon. If ethical misconduct of the grossest kind is in fact increasing - and there is a widespread view among judges and bar leaders that it is - the reasons for the increase are, as pointed out before, structural and systemic, a function of sharply increased competition among firms for business, and among lawyers within firms for a share of "you eat what you kill" compensation. To hold and attract litigation clients nowadays, a law firm and lawyers within the firm have to acquire a reputation as killer, big-winner litigators. In a big case, the temptations to conceal documents, abuse discovery, make strategic use of sanctions, distort precedent, and ignore harm done to third parties and the public interest are immense. It is not surprising that partners and associates should sometimes give in to them; or that some firms should gradually develop an ethical culture in which, because "everybody does it," doing it is just tit-for-tat behavior in the jungle where one must try to survive. In the abstract every lawyer involved may know at some level that this sort of behavior is "wrong" - but the capacity for denial and rationalization when large interests are at stake is very great.

Yet every time I go to a bar meeting or conference, I hear that lawyers and judges who deplore this situation want the schools to fix it up by teaching better ethics! Well, I think we can teach ethics better

82. I cannot emphasize enough this vital but neglected component of legal education. Much of practitioners" most valuable practical knowledge is not in the least doctrinal. Some of it is intensely local knowledge - what the judges are like, which court clerks are cooperative, local procedural customs - and there is no point trying to teach that in law school. Some is craft knowledge, best taught through apprenticeship. But some is overall knowledge of structural and institutional features - how fee arrangements structure incentives to sue and settle; how discovery and sanction rules may affect strategy; how police, prosecutors and parole officers see their work and ordinarily behave; and so forth - that the systematic inquiry of scholars can grasp, and write up in ways that can, in turn, be taught to students. 62-63.

83. Judge Edwards seems generally to concur with this last point. Edwards, supra note 1, at 
in the schools than we do, and it might do some good if we did. What we need for this purpose are exercises that put students in practice situations much like the ones they are going to occupy, with lots of pressure from partners and clients to commit or overlook ethical violations. We can teach them how to recognize and analyze ethical problems of practice. We can also teach - and would be able to teach a lot better if there were more empirical studies of practice - more about the structures of practice, the client relationships, the compensation systems, and the politics of bar discipline that are likely to produce ethical violations. We can recommend ways to reform the system to offset its perverse incentives - through sanctions, through more effective regulation by outside agencies, through whistleblower protection, through installation of ombudsmen or review committees within law firms for lawyers who are being pressured into dubious conduct to consult, through revised compensation schemes that would impose heavy penalties within firms for ethical violations, and, yes, through moral education conducted jointly by the schools and respected senior bar leaders and judges. Moreover, our graduates, when they become partners and law reformers themselves, can try to get these reforms adopted. Structural problems require structural reforms. No amount of moralizing to lawyers by the schools, the bar elite, or the judiciary is going to accomplish much unless it changes the system to change the incentives. The methods described above would all be very practical teaching indeed, though they have virtually no connection with doctrine.

But none of these suggestions will ultimately do any good at all unless adopted by the powerful people in practice - under Judge Edwards' hypothesis, the lawyers responsible for creating the culture that encourages the misconduct in the first place. We can advise the student about to become a law firm associate that, if a partner tells her to destroy a document, she should go up the hierarchy and consult a respected senior partner. But suppose the senior partner backs up the junior? The associate can refuse of course, at the risk of being fired, or quit. But what signal will these actions send to the other associates? Why, that sticking to your principles is naive and will do you in. This problem is not one that their law schools, with or without the assistance of splendid doctrinal teaching, can solve. When the bench and bar look to the law schools to solve problems by teaching virtue that practitioners could realistically only address by taking collective action themselves to toughen ethical standards, restructuring organizations like law firms, and imposing meaningful sanctions, it is a sign that their interest in reform is mostly symbolic. 


\section{CODA}

In looking over this piece, I see I have painted a rather radiant, even Panglossian picture of legal scholarship. In truth it has been my intention to present legal scholarship in its most favorable aspects and to defend it against attacks that seem to me unfair and inaccurate as well as in some part justified. The fact that many practitioners do not appreciate the practical value of nondoctrinal scholarship - especially theoretical, interdisciplinary, and critical work - does not mean that it has none, though it may well mean that we ought to work much harder to make its utility apparent. Yet, though I really think the legal academy has improved enormously since my own law schooling in the late 1960s, it is nothing about which to be smug. Legal scholarship is still overwhelmingly preoccupied with doctrine, case law, and the judge-centered model of the legal process to the relative neglect of legislation and administration, the counseling and transactional dimensions of law practice, and the sustained study of the policies and values underlying legal practices. It is also hugely, disproportionately, focused on the sexy issues of public law, especially constitutional law. Teaching is still mostly parsing cases instead of problem-based and clinical. Some of the new wave of scholarship does indeed seem horribly pretentious and vacuous - schlock economics, schlock history, schlock philosophy, schlock poststructuralist theory - with little promise of helping anybody to understand the legal world or work in it or transform it. Almost all the articles are far too long. ${ }^{84}$ Empirical or law-in-action work of all kinds is underdone and undervalued.

Not that much, in short, has changed. Law teachers are mostly plowing and planting on the old "middle ground" between the reflective world of the university and the active world of the practitioner. As they always have, they are describing and analyzing the practices of lawyers - all too often unfortunately only the doctrinal practices - finding their normative bases in policy and principle and suggesting ways of improving the practices to make them serve the principles and policies better. To switch metaphors, the scholars are still walking the tightrope between frankly speaking truth to the powerful and adopting enough of the discourse and conventions of the powerful to have some influence in their world. This kind of work has, since the beginning of the university law school, been theoretical, interdisciplinary, and at least somewhat critical. It may well be that in recent years the theory has become more formal, the interdisciplinary component less ama-

84. I say this with some sheepishness because this piece was originally planned as a tenpager. 
teurish, and the criticism more intense - reflecting both prevailing intellectual tendencies and the increasing political diversity of the academic as well as of the practicing profession. But legal scholarship is still primarily the earnest and high-minded work of legal improvement. Most scholars continue to assume that the managers of the legal system want the system to work justly and efficiently and to serve its best purposes; and that when deficiencies are pointed out, and rational arguments made for amendment, concerned lawyers will respond with dialogue and collaborate in the reform effort, if necessary even against their own and their clients' immediate interests. Judge Edwards is clearly such a concerned lawyer himself. Yet much of what he and his survey sample have to say is a chilling reminder of the ways in which the practical agenda of legal scholarship - despite its record of undeniable successes - is often just an intellectuals' dream fantasy of rationalist authority and influence over a profession that no longer exists, a play enacted to an empty theater. 